\begin{tabular}{|lcl|}
\hline \multicolumn{3}{|c|}{ TOTOBUANG } \\
\hline Volume 6 & Nomor 1, Juni 2018 & Halaman 139—154 \\
\hline
\end{tabular}

\title{
STRATEGI PENANGANAN SOAL UKBI MENURUT DIMENSI SOAL FAKTUAL (Strategies of UKBI Question Management Based on Dimension of Factual Question)
}

\author{
Nanik Sumarsih \\ Balai Bahasa Daerah Istimewa Yogyakarta \\ Jalan I Dewa Nyoman Oka 34, kotabaru, Yogyakarta \\ Pos-el: nanikbudiyantoro@gmail.com
}

(Diterima: 15 Februari 2018; Direvisi 13 Mei 2018; Disetujui: 3 Juni 2018)

\begin{abstract}
This study discussed about the skill level of junior and senior high school teachers at Yogyakarta in answering the factually UKBI and handled question strategy according to factual question dimension.This research used descriptive quantitative approach.The research aimed to determine the good or poor languagelevel of the educators which had been measured by UKBI. Therefore, the result of this study wa originally presented by considering its productivity.The research followed several steps, they were: (1) collecting and classifying of data, (2) analysing data, (3) presenting analysis result.The ability of junior and senior high school teachers at DIY in answeingr factual question was $81 \%$. Based on the character of factual question, the strategy that should be used was that applying 5W 1H strategy (who, what, where, when, why, and how)_. This strategy can be described as follows: Who is asking about a person as doer. What is asking about an event that happens. Where is asking about where an event takes place. When is asking time when an event happens. Why is asking about reason why it happens. How is asking how an event happens.
\end{abstract}

Keywords: Language Proficiency, UKBI, Factual Question

\begin{abstract}
Abstrak
Kajian ini membahas tingkat kemahiran guru SLTP dan SLTA di Yogyakarta dalam menjawab soal UKBI yang bersifat faktual beserta strategi penanganan soal menurut dimensi soal faktual. Penelitian ini menggunakan pendekatan kuantitatif deskriptif. Hal ini dimaksudkan untuk menentukan baik buruk kemampuan berbahasa pendidik yang diukur berdasarkan UKBI. Oleh karena itu, hasil penelitian ini memaparkan apa adanya dengan mempertimbangkan produktivitasnya. Langkah penelitian mengikuti tahapan sebagai berikut. Pertama, pencarian dan klasifikasi data. Kedua, analisis data. Ketiga, penyampaian hasil analisis. Kemampuan guru SLTP dan SLTA di DIY dalam menjawab soal yang bersifat faktual masing-masing adalah $81 \%$. Berdasarkan sifat soal faktual, strategi yang dapat digunakan untuk menjawab bentuk penyoalan ini adalah $5 \mathrm{~W}$ $1 H$ (who, what, where, when, why, dan how)_Strategi ini dapat dijabarkan sebagai berikut. Who ialah tentang siapa? What, apa yang terjadi? Where, di mana peristiwa itu terjadi, when, kapan hal itu terjadi? Why, mengapa hal itu terjadi? How, bagaimana hal itu terjadi?
\end{abstract}

Kata Kunci: Kemahiran Berbahasa, UKBI, Soal Faktual

\section{PENDAHULUAN}

Berdasarkan penelitian terbatas pada tahun 2011 yang dilakukan oleh Solihah (2014:5) diketahui bahwa kemahiran guru di provinsi dengan UN rendah juga memperlihatkan hasil UKBI yang rendah. Sebaliknya, kemahiran berbahasa guru di provinsi yang perolehan UN tinggi juga menunjukkan kemahiran yang baik. Jadi, terdapat hubungan yang cukup signifikan antara kemahiran berbahasa Indonesia guru dengan perolehan UN siswa untuk mata pelajaran Bahasa Indonesia. Sehubungan dengan hal tersebut, dapat dikatakan bahwa guru yang memiliki kemahiran berbahasa Indonesia yang rendah ternyata dapat berimplikasi pada hasil belajar siswanya, khususnya untuk pelajaran Bahasa Indonesia.

Rendahnya kemampuan berbahasa Indonesia berdampak pada rendahnya kemampuan membaca dan kemampuan 
menulis siswa. Setidaknya guru harus memperoleh skor pada tingkat unggul agar dapat berdampak pada pembelajaran bahasa Indonesia yang menyenangkan dan mampu meningkatkan nilai UN bahasa Indonesia, sekaligus mengefektifkan proses pembelajaran yang ada.

Selain hasil UN bahasa Indonesia, isu strategis lain berkaitan dengan hasil PISA (Programme for International Student Assessment) dalam hal literasi membaca yang menyatakan bahwa pada tahun 2015 Indonesia meraih peringkat 64 dari 72 negara. Hal tersebut disebabkan oleh siswa Indonesia tidak dapat menjawab soal-soal yang bersifat analitis. Karena memang sampai saat ini, belum menjadi bagian dari proses pembelajaran sekolah-sekolah di Indonesia.

Terkait hal tersebut, sistem penyoalan dalam UKBI menawarkan konsep-konsep pemecahan masalah yang selama ini belum diterapkan di sekolahsekolah. Terdapat tiga jenis penyoalan dalam penyusunan soal UKBI. Salah satu jenis penyoalan adalah jenis penyoalan yang bersifat faktual. Penyoalan faktual adalah penyoalan mengenai pengetahuan tentangterminologi, detail, dan unsur (kejadian, detail, waktu, tempat, ukuraan, subjek tertentu).

Kajian mengenai strategi penanganan soal UKBI ini perlu dilakukan guna memberi wawasan kepada calon peserta uji agar lebih mudah memahami soal saat mengikuti tes UKBI. Kajian penelitian ini berjudul "Strategi Penanganan Soal UKBI Menurut Dimensi Soal Faktual". Penelitian ini bertujuan untuk memperoleh pemetaan tingkat kemahiran guru di DIY dalam menjawab soal yang bersifat faktual beserta strategi penanganan soalnya.

\section{LANDASAN TEORI}

Terdapat tiga dimensi penyoalan dalam UKBI, yaitu faktual, konseptual, dan prosedural (Maryanto, 2009:1-2). Dimensi penyoalan yang bersifat faktual yaitu pengetahuan tentangterminologi, detail, dan unsur (kejadian, detail, waktu, tempat, ukuraan, dan subjek tertentu). Dimensi penyoalan yang bersifat konseptual, yaitu pengetahuan tentang klasifikasi dan kategori; pengetahuan tentang berbagai prinsip dan generalisasi serta pengetahuan tentang berbagai teori, struktur, dan model. Dimensi penyoalan yang bersifat prosedural, yaitu pengetahuan tentang berbagai kecakapan khusus dan logaritma, pengetahuan tentang berbagai teknik khusus dan metode, dan pengetahuan tentang kriteria tertentu untuk menentukan kapan harus menggunakan prosedur yang tepat (Solihah, 2014:27-32).

Dimensi soal yang bersifat faktual memiliki ciri jawaban beracuan konkret (eksplisit di dalam teks atau wacana), jawaban berupa ingatan atau pemahaman, dan jawaban tidak memerlukan analisis. Dimensi soal yang bersifat konseptual memiliki ciri jawaban beracuan semi abstrak (implisit atau semiimplisit di dalam teks atau wacana), jawaban berupa penerapan atau jawaban memerlukan analisis, dan jawaban bukan berupa ingatan atau pahaman. Dimensi soal yang bersifat prosedural memiliki ciri jawaban beracuan abstrak (implisit di dalam teks/wacana), jawaban memerlukan analisis yang kompleks, dan jawaban memerlukan evaluasi.

Selain dimensi penyoalan, penyusunan soal UKBI juga memperhatikan ranahnya. Ranah adalah lingkungan yang memungkinkan terjadinya komunikasi, misalnya ranah ekonomi, ranah pertanian, ranah agama, dan ranah politik. Setiap ranah mencerminkan tingkat kerumitan yang berbeda berdasarkan kekhasan peristilahan. Penyoalan di dalam UKBI tidak dibatasi pada ranah tertentu, tetapi justru seberagam mungkin. Terdapat empat ranah yang digunakan dalam penyoalan UKBI, yaitu (1) sintas, (2) sosial, (3) vokasional, dan (4) akademik (Solihah, 2014:5-16).

Sintas memperlihatkan kesadaran berkomunikasi untuk kepentingan personal di tempat umum, misalnya komunikasi yang 
terwujud ketika seseorang membeli sesuatu di warung atau di perpustakaan. Fokus penceritaan pada kebutuhan atau keinginan orang/individu. Dengan wacana sintas, sekurang-kurangnya peserta uji dapat memahami bagaimana mengungkapkan diri, menyadari eksistensi diri atau potensi diri sebagai makhluk Tuhan, dan menyadari diri sebagai bagian dari keluarga dan lingkungan.

Sosial memperlihatkan gambaran tentang kesadaran berkomunikasi untuk kepentingan interpersonal yang merupakan komunikasi yang terwujud dalam mengekspresikan kerja sama, kepedulian, keperihatinan, dan kepekaan terhadap orang lain. Misalnya, ungkapan kepedulian terhadap dampak bencana alam dan ungkapan dalam membangun kerja sama dengan orang lain dalam arisan. Fokus penceritaan pada hubungan individu dan sesama anggota masyarakat. Dengan wacana sosial sekurang-kurangnya peserta uji dapat memahami bagaimana menjalin komunikasi dengan orang lain dalam rangka menjalin kerja sama, mengungkapkan kepedulian, mengungkapkan gagasan dalam meningkatkan hubungan, dan sebagainya.

Vokasional memperlihatkan kesadaran berkomunikasi mengenai perilaku produktif untuk menghasilkan barang atau jasa, misalnya pembuatan lem, penggunaan kamera, cara bertanam, konsultasi kesehatan, dan konsultasi hukum.

Akademik memperlihatkan kesadaran berkomunikasi mengenai perilaku keilmiahan untuk pengembangan ilmu dan pengetahuan, misalnya temuan ilmiah, diskusi ilmiah, laporan iptek, dan orasi ilmiah.

\section{METODE PENELITIAN}

Ada tiga tahapan dalam pelaksanaan penelitian ini, yaitu tahap pengumpulan data, tahap analisis data, dan tahap penyajian hasil analisis data (Sudaryanto 1993:5).
Pemaparan ketiga tahap tersebut sebagai berikut.

Data penelitian ini adalah tingkat kemahiran berbahasa Indonesia guru di Daerah Istimewa Yogyakarta berdasar hasil UKBI. Mengingat banyaknya guru yang telah mengikuti UKBI, dalam penelitian ini akan dibatasi untuk guru SLTP dan SLTA di Daerah Istimewa Yogyakarta yang mengikuti UKBI pada rentang uji tahun 2012-2013. Berkaitan dengan itu, data berupa hasil UKBI didapatkan dari tim UKBI Balai Bahasa DIY. Sumber data berupa template-template penilaian yang telah dilakukan oleh tim UKBI Balai Bahasa DIY.

Penelitian ini menggunakan pendekatan kuantitatif deskriptif. Hal ini dimaksudkan untuk menentukan baik buruk kemampuan berbahasa pendidik diukur berdasarkan UKBI. Oleh karena itu, hasil penelitian ini dipaparkan apa adanya dengan mempertimbangkan produktivitasnya.

Analisis data dilakukan dengan metode agih. Metode agih adalah metode yang pelaksanaannya menggunakan unsur penentu yang berupa unsur bahasa itu sendiri (Sudaryanto 1993:13-15). Pemanfaatkan metode ini untuk menangani model penyoalan yang memang memanfaatkan aspek-aspek kebahasaan, baik secara semantik, gramatikal, maupun pragmatik. Aspek semantik diterapkan apabila penyoalan berupa peristilahan atau pilihan kata; aspek gramatikal diterapkan apabila penyoalan berupa pengalimatan; dan aspek pragmatik diterapkan apabila penyoalan berupa tuturan.

Metode ini diterapkan dengan cara mengamati hasil uji yang telah dilakukan. Hasil uji yang telah dilakukan dipilih yang benar berdasarkan dimensi penyoalan UKBI. Dimensi penyoalan dalam UKBI dibedakan menjadi tiga, yaitu (1) faktual, (2) konseptual, dan (3) prosedural.

Penyajian hasil analisis menggunakan metode formal dan informal. Metode formal digunakan sebagai alat bantu 
penjelasan, ditampilkan beberapa tabel dan bagan. Dengan metode informal, hasil penelitian ini dideskripsikan dengan menggunakan ekspresi tulis bahasa Indonesia.

\section{PEMBAHASAN}

Tingkat Kemahiran Guru SLTP dan SLTA di Yogyakarta dalam Menjawab Soal yang Bersifat Faktual

Pada bagian ini akan dipaparkan hasil tes UKBI terhadap soal faktual. Hasil tes tersebut meliputi jawaban terhadap soalsoal tes yang berupa soal faktual. Hasil tes tersebut dipilah berdasar kelompok guru SLTP dan guru SLTA.

Tingkat Kemahiran Guru SLTP dalam Menjawab Soal yang Bersifat Faktual

Peserta guru Bahasa Indonesia tingkat SLTP di Daerah Istimewa Yogyakarta yang mengikuti tes UKBI sebanyak seratus orang. Sejumlah peserta tersebut telah mengerjakan soal UKBI termasuk soal faktual pada tes UKBI ini yang berjumlah 22 soal. Jawaban soal faktual peserta UKBI guru Bahasa Indonesia tingkat SLTP di Daerah Istimewa Yogyakarta dapat diamati pada tabel 1 berikut.

Tabel 1

Tingkat Kemahiran Guru SLTP di DIY dalam Menjawab Soal yang Bersifat Faktual

\begin{tabular}{|c|c|c|c|c|}
\hline No. & $\begin{array}{c}\text { Jumlah Jawaban } \\
\text { Benar }\end{array}$ & $\begin{array}{c}\text { Jumlah Peserta } \\
\text { yang Menjawab } \\
\text { Benar }\end{array}$ & $\begin{array}{c}\text { Persentase } \\
(\%)\end{array}$ & $\begin{array}{c}\text { Rerata } \\
\text { Jumlah } \\
\text { Jawaban } \\
\text { Benar }\end{array}$ \\
\hline 1. & 11 & 2 & 2 & \multirow{12}{*}{$\begin{array}{c}18 \\
(1805: 100)\end{array}$} \\
\hline 2. & 12 & 2 & 2 & \\
\hline 3. & 13 & 3 & 3 & \\
\hline 4. & 14 & 1 & 1 & \\
\hline 5. & 15 & 3 & 3 & \\
\hline 6. & 16 & 7 & 7 & \\
\hline 7. & 17 & 16 & 16 & \\
\hline 8. & 18 & 19 & 19 & \\
\hline 9. & 19 & 18 & 18 & \\
\hline 10. & 20 & 18 & 18 & \\
\hline 11. & 21 & 9 & 9 & \\
\hline 12. & 22 & 2 & 2 & \\
\hline
\end{tabular}

Berdasarkan tabel 1 peserta yang mampu menjawab 11 soal faktual dengan benar adalah 2 orang atau 2 persen. Peserta yang mampu menjawab 12 soal faktual dengan benar adalah 2 orang atau 2 persen. Peserta yang mampu menjawab 13 soal faktual dengan benar adalah 3 orang atau 3 persen. Peserta yang mampu menjawab 14 soal faktual dengan benar adalah 1 orang atau 1 persen. Peserta yang mampu menjawab 15 soal faktual dengan benar adalah 3 orang atau 3 persen. Peserta yang mampu menjawab 16 soal faktual dengan benar sejumlah 7 orang atau 7 persen. Peserta yang mampu menjawab 17 soal faktual dengan benar sejumlah 16 orang atau 16 persen. Peserta yang mampu menjawab 18 soal faktual dengan benar sejumlah 19 orang atau 19 persen. Peserta yang mampu menjawab 19 soal faktual dengan benar sejumlah 18 orang atau 18 persen. Peserta yang mampu menjawab 20 soal faktual dengan benar sejumlah 18 orang atau 18 persen. Peserta yang mampu menjawab 21 
soal faktual dengan benar sejumlah 9 orang atau 9 persen. Peserta yang mampu menjawab 22 soal faktual dengan benar sejumlah 2 orang atau 2 persen.

Kemampuan guru Bahasa Indonesia tingkat SLTP di Daerah Istimewa Yogyakarta secara umum dalam menjawab soal faktual dapat diketahui dengan cara menentukan rerata jumlah peserta yang mampu menjawab soal dengan benar. Berdasarkan jumlah jawaban tersebut dapat diketahui rerata dari jumlah jawaban yang benar seluruh peserta UKBI pada data penelitian ini. Rerata yang diperoleh dari jumlah peserta yang mampu menjawab soal faktual dengan benar adalah 18 jawaban benar.

Dari hasil rerata yang telah diperoleh tersebut dapat dicari simpangan baku untuk menentukan batas toleransi peserta yang masih dianggap layak memiliki kemampuan rata-rata. Untuk memperoleh simpangan baku tersebut digunakan rumus yang telah ditentukan yaitu dengan $\sqrt{\frac{\sum X^{2}}{N}}$.

Tabel 2

Predikat Tingkat Kemahiran Guru SLTP di DIY dalam Menjawab Soal yang Bersifat Faktual

Berdasar Simpangan Baku

\begin{tabular}{|c|c|c|c|c|}
\hline No. & $\begin{array}{c}\text { Jumlah } \\
\text { Jawaban } \\
\text { Benar }\end{array}$ & $\begin{array}{c}\text { Jumlah Peserta } \\
\text { yang } \\
\text { Menjawab } \\
\text { Benar }\end{array}$ & Nilai $\mathbf{X}^{2}$ & Predikat \\
\hline 1. & 11 & 2 & $X 1=-7 \rightarrow 49$ & \multirow{4}{*}{ Sangat tidak Mampu } \\
\hline 2. & 12 & 2 & $X 2=-6 \rightarrow 36$ & \\
\hline 3. & 13 & 3 & $X 3=-5 \rightarrow 25$ & \\
\hline 4. & 14 & 1 & $X 4=-4 \rightarrow 16$ & \\
\hline 5. & 15 & 3 & $X 5=-3 \rightarrow 9$ & Tidak Mampu \\
\hline 6. & 16 & 7 & $X 6=-2 \rightarrow 4$ & Kurang Mampu \\
\hline 7. & 17 & 16 & $X 7=-1 \rightarrow 1$ & Agak Mampu \\
\hline 8. & 18 & 19 & $\mathrm{X} 8=0 \rightarrow 0$ & Cukup Mampu \\
\hline 9. & 19 & 18 & $X 9=1 \rightarrow 1$ & Mampu \\
\hline 10. & 20 & 18 & $\mathrm{X} 10=2 \rightarrow 4$ & \multirow{3}{*}{ Sangat Mampu } \\
\hline 11. & 21 & 9 & $\mathrm{X} 11=3 \rightarrow 9$ & \\
\hline 12. & 22 & 2 & $X 12=4 \rightarrow 16$ & \\
\hline & $\begin{array}{l}\frac{\sum X^{2}}{\sum X^{2}} \\
\frac{N}{\sqrt{\frac{\sum X^{2}}{N}}}\end{array}$ & & \multicolumn{2}{|l|}{$\begin{array}{l}170 \\
170: 100=1,7 \\
\sqrt{ } 1,7=1,3\end{array}$} \\
\hline
\end{tabular}

Berdasarkan tabel 2 dapat dinyatakan bahwa peserta yang mendapat predikat sangat tidak mampu adalah peserta yang mengerjakan soal dengan benar sebanyak 11, 12, 13, dan 14 soal. Dalam hal ini terdapat 8 orang yang memiliki predikat sangat tidak mampu. Peserta yang mendapat predikat tidak mampu adalah peserta yang mengerjakan soal dengan benar sebanyak 15 soal. Dengan kata lain terdapat 3 orang yang 
memiliki predikat tidak mampu. Peserta yang mendapat predikat kurang mampu adalah peserta yang mengerjakan soal dengan benar sebanyak 16 soal. Pada predikat ini terdapat 7 orang yang memiliki predikat kurang mampu. Peserta yang mendapat predikat agak mampu adalah peserta yang mengerjakan soal dengan benar sebanyak 17 soal. Dalam pengertian ini terdapat 16 orang yang memiliki predikat agak mampu. Peserta yang mendapat predikat mampu adalah peserta yang mengerjakan soal dengan benar sebanyak 19 soal. Pada capaian ini terdapat 18 orang yang memiliki predikat mampu. Peserta yang mendapat predikat sangat mampu adalah peserta yang mengerjakan soal dengan benar sebanyak 20, 21, dan 22 soal. Dalam hal ini terdapat 29 orang yang memiliki predikat sangat mampu.

Berdasarkan perolehan predikat tersebut dapat disimpulkan bahwa terdapat 34 orang peserta yang hanya dapat meraih predikat di bawah rerata, yaitu mereka yang mendapat predikat sangat tidak mampu, tidak mampu, kurang mampu, dan agak mampu. Sementara itu, terdapat 47 peserta yang meraih predikat di atas rerata, yaitu mereka yang mendapat predikat mampu dan sangat mampu. Oleh karena itu, perlu dilakukan pelatihan strategi mengerjakan soal faktual terutama kepada 34 peserta guru Bahasa Indonesia yang hanya mampu meraih predikat sangat tidak mampu, tidak mampu, kurang mampu, dan agak mampu.

\section{Tingkat Kemahiran Guru SLTA dalam} Menjawab Soal yang Bersifat Faktual

Seperti halnya peserta UKBI guru Bahasa Indonesia tingkat SLTP, peserta UKBI guru Bahasa Indonesia tingkat SLTA di Daerah Istimewa Yogyakarta yang mengikuti tes UKBI pada data penelitian ini sebanyak seratus orang. Seluruh peserta tersebut telah mengerjakan soal UKBI termasuk soal faktual pada tes UKBI yang berjumlah 22 soal. Jawaban soal faktual peserta guru Bahasa Indonesia tingkat SLTA di Daerah Istimewa Yogyakarta dapat diamati pada tabel berikut ini.

Tabel 3

Tingkat Kemahiran Guru SLTA di DIY dalam Menjawab Soal yang Bersifat Faktual

\begin{tabular}{|c|c|c|c|c|}
\hline No. & $\begin{array}{c}\text { Jumlah Jawaban } \\
\text { Benar }\end{array}$ & $\begin{array}{c}\text { Jumlah Peserta } \\
\text { yang Menjawab } \\
\text { Benar }\end{array}$ & $\begin{array}{c}\text { Persentase } \\
(\%)\end{array}$ & $\begin{array}{c}\text { Rerata } \\
\text { Jumlah } \\
\text { Jawaban } \\
\text { Benar }\end{array}$ \\
\hline 1. & 10 & 1 & 1 & \multirow{13}{*}{$\begin{array}{c}18 \\
(1797: 100)\end{array}$} \\
\hline 2. & 11 & 1 & 1 & \\
\hline 3. & 12 & - & - & \\
\hline 4. & 13 & 3 & 3 & \\
\hline 5. & 14 & 3 & 3 & \\
\hline 6. & 15 & 6 & 6 & \\
\hline 7. & 16 & 11 & 11 & \\
\hline 8. & 17 & 16 & 16 & \\
\hline 9. & 18 & 9 & 9 & \\
\hline 10. & 19 & 19 & 19 & \\
\hline 11. & 20 & 20 & 20 & \\
\hline 12. & 21 & 8 & 8 & \\
\hline 13. & 22 & 3 & 3 & \\
\hline
\end{tabular}


Berdasarkan tabel 3 tersebut dapat dikatakan bahwa peserta yang mampu menjawab 10 soal faktual dengan benar adalah 1 orang atau 1 persen. Peserta yang mampu menjawab 11 soal faktual dengan benar adalah1 orang atau 1 persen. Peserta yang mampu menjawab 13 soal faktual dengan benar adalah 3 orang atau 3 persen. Peserta yang mampu menjawab 14 soal faktual dengan benar adalah 3 orang atau 3 persen. Peserta yang mampu menjawab 15 soal faktual dengan benar adalah 6 orang atau 6 persen. Peserta yang mampu menjawab 16 soal faktual dengan benar sejumlah 11 orang atau 11 persen. Peserta yang mampu menjawab 17 soal faktual dengan benar sejumlah 16 orang atau 16 persen. Peserta yang mampu menjawab 18 soal faktual dengan benar sejumlah 9 orang atau 9 persen. Peserta yang mampu menjawab 19 soal faktual dengan benar sejumlah 19 orang atau 19 persen. Peserta yang mampu menjawab 20 soal faktual dengan benar sejumlah 20 orang atau 20 persen. Peserta yang mampu menjawab 21 soal faktual dengan benar sejumlah 8 orang atau 8 persen. Peserta yang mampu menjawab 22 soal faktual dengan benar sejumlah 3 orang atau 3 persen.

Berdasarkan tabel tersebut dapat disimpulkan bahwa jumlah jawaban benar paling banyak dikerjakan peserta adalah 22 jawaban yang benar dari 22 soal faktual. Dari jawaban tersebut, peserta yang menjawab 22 soal dengan benar sebanyak 3 orang atau 3 persen. Sementara itu, jumlah jawaban benar yang paling sedikit dikerjakan oleh peserta adalah 10 jawaban. Peserta yang menjawab 10 sebanyak 1 orang atau sebanyak 1 persen.

Kemampuan secara umum untuk menjawab soal UKBI guru Bahasa Indonesia tingkat SLTA di Daerah Istimewa Yogyakarta dapat diketahui dengan cara menentukan rerata jumlah peserta yang mampu menjawab soal dengan benar. Berdasarkan jumlah jawaban tersebut dapat diketahui rerata dari jumlah jawaban yang benar seluruh peserta UKBI pada data penelitian ini. Rerata yang diperoleh dari jumlah peserta yang mampu menjawab soal UKBI dengan benar adalah 18 jawaban yang benar.

Dari hasil rerata yang telah diperoleh tersebut dapat dicari simpangan baku untuk menentukan batas toleransi peserta yang masih dianggap layak memiliki kemampuan rata-rata. Untuk memperoleh simpangan baku tersebut digunakan rumus yang telah ditentukan yaitu dengan $\sqrt{\frac{\sum X^{2}}{N}}$.

Tabel 4

Predikat Tingkat Kemahiran Guru SLTA di DIY dalam Menjawab Soal yang Bersifat Faktual Berdasar Simpangan Baku

\begin{tabular}{|c|c|c|c|c|}
\hline No. & $\begin{array}{c}\text { Jumlah } \\
\text { Jawaban } \\
\text { Benar }\end{array}$ & $\begin{array}{c}\text { Jumlah Peserta } \\
\text { yang } \\
\text { Menjawab } \\
\text { Benar }\end{array}$ & Nilai $X^{2}$ & Predikat \\
\hline 1. & 10 & 1 & $X 1=-8 \rightarrow 64$ & \multirow{2}{*}{ Sangat tidak Mampu } \\
\hline 2. & 11 & 1 & $X 2=-7 \rightarrow 49$ & \\
\hline 3. & 12 & - & $X 3=-6 \rightarrow 36$ & \multirow{2}{*}{ Tidak Mampu } \\
\hline 4. & 13 & 3 & $X 4=-5 \rightarrow 25$ & \\
\hline 5. & 14 & 3 & $X 5=-4 \rightarrow 16$ & \multirow{2}{*}{ Kurang Mampu } \\
\hline 6. & 15 & 6 & $X 6=-3 \rightarrow 9$ & \\
\hline
\end{tabular}


Totobuang, Vol. 6, No. 1, Juni 2018: 139-154

\begin{tabular}{|c|c|c|l|l|}
\hline 7. & 16 & 11 & $\mathrm{X} 7=-2 \rightarrow 4$ & \multirow{2}{*}{ Agak Mampu } \\
\hline 8. & 17 & 16 & $\mathrm{X} 8=-1 \rightarrow 1$ & \multirow{2}{*}{ Cukup Mampu } \\
\hline 9. & 18 & 9 & $\mathrm{X} 9=0 \rightarrow 0$ & \multirow{2}{*}{ Mampu } \\
\hline 10. & 19 & 19 & $\mathrm{X} 10=1 \rightarrow 1$ & \multirow{2}{*}{ Sangat Mampu } \\
\hline 11. & 20 & 20 & $\mathrm{X} 11=2 \rightarrow 4$ & \\
\hline 12. & 21 & 8 & $\mathrm{X} 12=3 \rightarrow 9$ & \\
\hline 13. & 22 & 3 & $\mathrm{X} 13=4 \rightarrow 16$ & \\
& $\sum X^{2}$ & & 234 & \\
& $\frac{\sum X^{2}}{N}$ & & $\sqrt{ } 234: 34=1,53$ & \\
& $\sqrt{\frac{\sum X^{2}}{N}}$ & & & \\
& & & & \\
\end{tabular}

Berdasarkan tabel tersebut dapat dinyatakan bahwa peserta yang mendapat predikat sangat tidak mampu adalah peserta yang mengerjakan soal dengan benar sebanyak 10 dan 11 soal. Dalam hal ini terdapat 2 orang yang memiliki predikat sangat tidak mampu. Peserta yang mendapat predikat tidak mampu adalah peserta yang mengerjakan soal dengan benar sebanyak 12 dan 13 soal. Dengan kata lain terdapat 3 orang yang memiliki predikat tidak mampu. Peserta yang mendapat predikat kurang mampu adalah peserta yang mengerjakan soal dengan benar sebanyak 14 dan 15 soal. Pada kondisi ini terdapat 9 orang yang memiliki predikat kurang mampu. Peserta yang mendapat predikat agak mampu adalah peserta yang mengerjakan soal dengan benar sebanyak 16 dan 17 soal. Dalam pengertian ini terdapat 27 orang yang memiliki predikat agak mampu. Peserta yang mendapat predikat cukup mampu adalah peserta yang mengerjakan soal dengan benar sebanyak 18 soal. Dalam pengertian ini terdapat 9 orang yang memiliki predikat cukup mampu. Peserta yang mendapat predikat mampu adalah peserta yang mengerjakan soal dengan benar sebanyak 19 dan 20 soal. Pada capaian ini terdapat 39 orang yang memiliki predikat mampu. Peserta yang mendapat predikat sangat mampu adalah peserta yang mengerjakan soal dengan benar sebanyak 21 dan 22 soal. Dalam hal ini terdapat 11 orang yang memiliki predikat sangat mampu.

Berdasarkan perolehan predikat tersebut dapat disimpulkan bahwa terdapat 41 peserta yang hanya dapat meraih predikat di bawah rerata, yaitu mereka yang mendapat predikat sangat tidak mampu, tidak mampu, dan kurang mampu. Sementara itu, terdapat 50 peserta yang meraih predikat di atas rerata, yaitu mereka yang mendapat predikat mampu dan sangat mampu. Oleh karena itu, perlu dilakukan pelatihan strategi mengerjakan soal faktual terutama kepada 41 peserta guru Bahasa Indonesia tingkat SLTAyang hanya mampu meraih predikat sangat tidak mampu, tidak mampu, agak mampu, dan kurang mampu.

\section{Strategi Penanganan Soal Menurut Dimensi Soal Faktual}

Dimensi penyoalan dalam UKBI berupa dimensi pengetahuan. Ada tiga dimensi penyoalan, yaitu faktual, konseptual, dan prosedural. Faktual adalah pengetahuan tentang terminologi, detail, dan unsur (kejadian, detail, waktu, tempat, ukuran, subjek tertentu). Konseptual adalah pengetahuan tentang klasifikasi dan 
kategori, pengetahuantentang berbagai prinsip dan generalisasi, pengetahuantentang berbagai teori, struktur, dan model. Prosedural adalah pengetahuan tentang berbagai kecakapan khusus dan logaritma, pengetahuan tentang berbagai teknik khusus dan metode, pengetahuan tentang kriteria tertentu untuk menentukan kapan harus menggunakan prosedur yang tepat.

Dimensi pengetahuan tersebut diwujudkan dalam dimensi kognitif yang berupa mengingat, memahami, menganalisis, dan mengevaluasi (Solihah, 2014:25). Penyoalan yang menggunakan dimensi mengingat diwujudkan dengan cara mengungkapkan kembali, rekognisi (mengidentifikasi/mengenali). Penyoalan yang menggunakan dimensi memahami diwujudkan dengan cara menafsirkan, mengelompokkan, menyimpulkan, mengklasifikasi, membuat perbandingan, memberikan penjelasan. Penyoalan yang menggunakan dimensi menganalisis diwujudkan dengan cara membedakan, menyusun ulang, melengkapi, menguraikan, mengintegrasikan. Penyoalan yang menggunakan dimensi mengevaluasi diwujudkan dengan cara memberikan kritik (penilaian), membuat hipotesis. Berikut paparan lebih lanjut mengenai strategi penangan soal UKBI, yang bersifat faktual.

Dimensi penyoalan yang bersifat faktual merupakan dimensi penyoalan yang paling sederhana. Jawaban dari dimensi penyoalan ini beracuan konkret (eksplisit di dalam teks/wacana sehingga jawaban berupa ingatan/pemahaman dan tidak memerlukan analisis.

Pertanyaan faktual dapat berupa nama, identitas (misalnya, pria, wanita, anak-anak, dewasa, orang tua), profesi (misalnya, mahasiswa, guru), waktu, lokasi/tempat, bentuk, peristiwa/kejadian, jumlah, ukuran (panjang, luas, isi), jenis, alat, cara tindakan.
Berdasar sifat faktual tersebut strategi yang dapat digunakan untuk menjawab bentuk penyoalan ini adalah dengan menggunakan strategi $5 \mathrm{~W} 1 \mathrm{H}$, yaitu who, what, where, when, why, dan how. Strategi ini dapat dijabarkan sebagai berikut. Who ialah tentang siapa? What, apa yang terjadi? Where, di mana peristiwa itu terjadi, when, kapan hal itu terjadi? Why, mengapa hal itu terjadi? How, bagaimana hal itu terjadi?

\section{Who}

Kata tanya who berisi pertanyaan mengenai siapa. Contoh pertanyaan yang menggunakan kata tanya who. Siapa yang melakukan perbuatan itu? Siapa yang menjadi korban dari perbuatan itu? Siapa yang merasa dirugikan olehnya? Siapa yang menyuruhnya melakukan perbuatan itu? Siapa yang terlibat di dalam peristiwa itu?

\section{Dengarkanlah dialog berikut. "MEMILIH TEMPAT TINGAL" Pemain : Pasangan suami istri muda

Lokasi : Ruang pameran
perumahan

Istri : Jangan tergesa membeli ya.

Suami : Kita melihat-lihat dulu! Membeli rumah kan tidak seperti membeli pisang goreng. Banyak yang harus dipertimbangkan.

Istri : Menurutku, rumah haruslah nyaman, aman, dan tenteram. Rumah kan tempat melepas lelah sesudah seharian terkuras pekerjaan.

Suami : Yang juga perlu diperhatikan, yaitu lokasi dan kondisi. Lokasi harus mudah dicapai dengan transportasi umum. Yang kedua, kondisi. Artinya, kondisi lokasi bukan termasuk daerah rawan banjir, gempa, atau tanah longsor. Juga jauh dari pusat industri. 
Istri : Bagi kita, yang penting untuk beberapa tahun ke depan, yaitu jarak ke fasilitas pendidikan anak, minimal TK dan SD. Kalau lebih dari $1 \mathrm{~km}$, rasanya bisa merepotkan. Oya, lalu bagaimana juga dengan jarak ke fasilitas lain, seperti tempat ibadah, pasar, puskemas, lapangan olahraga, atau ruang terbuka hijau.

Suami : Aku setuju saja. Tapi, juga perlu kita pertimbangkan, yaitu kondisi lahan: datar atau miring. Sebaiknya, kita menghindari lahan miring.

Istri : Masih banyak, lho! Misalnya, perihal infrastruktur: tersedia tidaknya jaringan listrik, telepon, dan sumber air bersih.

Suami : Yang sepertinya sepele, tapi vital, misalnya, lancar tidaknya saluran pembuangan air limbah. Namun, yang juga tidak kalah penting ialah kelengkapan surat, baik untuk status tanah maupun perizinan. Terakhir, tentang kualitas bangunan. Harus diperiksa apakah kualitas sudah seperti yang disebutkan di brosur.

Istri : Wah, banyak yang harus kita perhatikan, termasuk mengecek lokasi! Jadi, sepakat tak tergesa membeli.

Intisari, No. 543, Oktober 2008:42

Pilihlah satu jawaban berikut yang menurut Anda benar dengan menyilang huruf A, B, C, atau D.

Siapakah pasangan pelaku dialog?
(A) suami istri
(B) teman bermain
(C) sahabat karib
(D) kakak adik

Jawaban pertanyaan di atas sudah tertera dalam dialog. Pertanyaan tersebut menanyakan siapakah pasangan yang ada di dalam dialog. Jawaban dari pertanyaan tersebut adalah opsi (A) suami isteri seperti yang tercantum dalam dialog.

\section{What}

Kata tanya what berisi pertanyaan mengenai permasalahan atau hal yang terjadi pada suatu peristiwa. Selain peristiwa, kata tanya ini juga dapat digunakan untuk menanyakan benda, permasalahan, pendapat, dan lain-lain. Contoh pertanyaan yang menggunakan kata tanya what 'apa'. Apa yang sebenarnya terjadi?; apa yang sedang dilakukan olehnya?; apa yang dibawa oleh si pelaku ?; apa permasalahannya?; apa yang akan dilakukan olehnya?

\section{Dengarkanlah dialog berikut.}

Dialog antara guru (G) dan murid (M) di ruang kelas

G : Ardy, kenapa kamu terlambat lagi?

M : Anu Bu, Ardy tadi di jalan menemukan dompet.

G : Mana dompetnya?

M : Sudah saya kembalikan, Bu.

$\mathrm{G}$ : Dikembalikan dimana?

M : Pada pemiliknya, karena di dalam dompet ada alamatnya.

G : Ardy, kamu itu sudah berkali-kali terlambat dan selalu ada alasan.

M : Ini bukan salah Ardy, Bu.

G : Ardy, Ardy, sudah banyak alasan yang kau katakan pada Bu guru.

M : Maafkan Ardy, Bu guru.

G : Sebagai hukumannya, sekarang kamu membuat hitungan di bukumu dariangka satu hingga angka seratus.

M : Ya, Bu guru.

G : Itu bel berbunyi, anak-anak boleh pulang, kecuali Ardy.

M : Ada apa Bu guru saya disuruh tinggal?

G : Ada yang akan ibu bicarakan kepadamu.

M : Tentang apa Bu?

$\mathrm{G} \quad$ : Ardy Bu guru sangat prihatin atas nilai ulanganmu yang semakin menurun. 
M : Maafkan Ardy Bu.

G : Ibu khawatir kamu tidak naik kelas.

M : Jangan Bu guru.

$\mathrm{G}$ : Ada syaratnya.

M : Apa Bu guru?

$\mathrm{G}$ : Mulai sekarang kamu harus rajin, tidak boleh terlambat lagi.

M : Ya, Bu guru.

G : Hanya ini yang bisa Ibu katakan. terserah kamu.

M : Maafkan atas kesalahan Ardy Bu, mulai besok Ardy tidak akan terlambat lagi.

Pilihlah satu jawaban berikut yang menurut Anda benar dengan menyilang huruf A, B, C, atau D.

Apa yang ditemukan Ardy di jalan?
(A) Tas
(B) SIM
(C) Dompet
(D) STNK

Jawaban dari dimensi penyoalan faktual bersifat eksplisit. Jawaban tertuang di dalam bacaan sehingga tidak memerlukan analisis. Seperti pada contoh di atas empat opsi jawaban yang tercantum dalam bacaan adalah opsi (C) dompet. Hal tersebut dapat dilihat dari bentuk pertanyaannya yang menggunakan kata tanya "apa" dan jawaban yang tercantum dalam dialog adalah dompet yaitu pada dialog berikut.

$$
\begin{array}{cl}
\text { G } \quad \text { Ardy, kenapa kamu terlambat } \\
\text { lagi? } \\
\text { M : Anu Bu, Ardy tadi di jalan } \\
\text { menemukan dompet }
\end{array}
$$

\section{Where}

Kata tanya where 'di mana'
mengandung pertanyaan-pertanyaan
mengenai tempat atau lokasi sebuah
peristiwa terjadi. Contoh pertanyaan yang
menggunakan kata tanya where. Di mana
peristiwa itu terjadi? Di mana berita itu
dimuat? Di mana dia bersembunyi? Di

mana dia tertangkap? Di mana permasalahan itu pertama kali muncul?

\section{Dengarkanlah dialog berikut. "MEMILIH TEMPAT TINGAL" \\ Pemain : Pasangan suami istri \\ muda \\ Lokasi : Ruang pameran
perumahan \\ Dialog selanjutnya sama seperti contoh \\ di atas}

Pilihlah satu jawaban berikut yang menurut Anda benar dengan menyilang huruf $A, B, C$, atau D.

Dimanakah dialog tersebut berlangsung?

(A) Di teras rumah

(B) Ruang pameran perumahan

(C) Kantor pemasaran rumah

(D) Di lahan perumahan

Jawaban pertanyaan di atas sudah tertera dalam dialog. Pertanyaan tersebut menanyakan dimanakah dialog tersebut berlangsung. Jawaban dari pertanyaan tersebut adalah opsi (B) ruang pameran perumahan seperti yang tercantum dalam dialog.

When

Kata tanya when 'kapan' berisi pertanyaan-pertanyaan mengenai waktu terjadinya peristiwa, berita atau cerita yang terjadi. Contoh pertanyaan yang menggunakan kata tanya kapan. Kapan peristiwa itu terjadi? Kapan dia melakukan perbuatan itu? Kapan dia datang ke tempat itu? Kapan dia tiba di lokasi kejadian? Kapan dia kembali ke rumahnya?

\section{Dengarkanlah dialog berikut.}

Dialog antara seorang dokter (D) dengan seorang penyiar $(\mathrm{P})$ di sebuah stasiun radio.

$\mathrm{P} \quad$ : "Saat ini produk-produk antiseptik kian marak di pasaran."

D : "Ya, masyarakat sekarang ingin selalu hidup bersih dan steril."

P : "Apakah penggunaan antiseptik ini sudah yang terbaik, Dok?' 
D : "Ada hasil pengujian di sejumlah laboratorium yang mengungkapkan bahwa bakteri belum tentu mati, justru semakin kuat."

P : : "Hmm... Lalu, kapan sebenarnya kita memerlukan produk-produk antikuman ini?"

D : "Sebenarnya tidak semua kuman merugikan. Pakailah pada saat memerlukan, misalnya memakai sabun yang mengandung antiseptik pada saat kita terkena penyakit kulit, menggunakan cairan antiseptik pada saat air yang kita pakai dalam kondisi yang tidak baik."

P : "Apakah produk-produk seperti sabun, pasta gigi, atau kosmetik yang mengandung antiseptik dan yang tidak mengandung antiseptik mempunyai perbedaan yang signifikan?"

D : "Menurut hasil penelitian tidak ada perbedaan yang signifikan penggunaan barang-barang yang mengandung antiseptik dan yang tidak. Yang penting adalah dilakukan dengan benar, seperti mencuci tangan dengan benar."

P : "Jadi, yang penting pola hidup sehat ya, Dok?"

D : "Iya, jangan mentang-mentang sudah memakai cairan antiseptik, jadi lupa mencuci tangan."

Pilihlah satu jawaban berikut yang menurut Anda benar dengan menyilang huruf A, B, C, atau D.

Kapan kita memerlukan produk-produk antikuman?

(A) setiap saat

(B) sesuka hati

(C) saat memerlukan

(D) kapan pun

Sama seperti pertanyaan yang lain, jawaban dari dimensi penyoalan faktual bersifat eksplisit. Pada contoh di atas empat opsi jawaban yang tercantum dalam bacaan adalah opsi (C) saat memerlukan. Hal tersebut dapat dilihat dari bentuk pertanyaannya yang menggunakan kata tanya "kapan" dan jawaban yang tercantum dalam dialog adalah saat memerlukan, yaitu pada dialog berikut.

P : :"Hmm... Lalu, kapan sebenarnya kita memerlukan produk-produk antikuman ini?"

D : "Sebenarnya tidak semua kuman merugikan. Pakailah pada saat memerlukan, misalnya memakai sabun yang mengandung antiseptik pada saat kita terkena penyakit kulit, menggunakan cairan antiseptik pada saat air yang kita pakai dalam kondisi yang tidak baik."

Why

Kata tanya why 'mengapa'mengandung pertanyaanpertanyaan mengenai alasan atau motivasi terjadinya sebuah peristiwa. Tidak selamanya penggunaan kata tanya ini menghasilkan soal yang bersifat faktual. Soal dikatakan bersifat faktual jika opsi jawaban tertera atau eksplisit di dalam bacaan. Contoh pertanyaan yang menggunakan kata tanya why 'mengapa'. Mengapa hal tersebut bisa terjadi? Mengapa dia melakukan itu? Mengapa dia pergi ke tempat itu? Mengapa dia mengatakan seperti itu? Mengapa peristiwa itu menjadi sangat heboh?

\section{Bacalah bacaan berikut!}

Nama rosella belakangan naik daun. Bukan cuma rasanya yang asemasem segar yang bikin orang rindu untuk mencicipinya lagi dan lagi. Kelopak bunganya yang merah cabai, diyakini juga sebagai obat mujarab pengusir puluhan jenis gangguan tubuh.

Nama rosella tiba-tiba menarik perhatian, tentu karena khasiatnya mengusir berbagai keluhan tubuh. Mulai 
dari yang ringan seperti menjaga stamina, menurunkan panas, menurunkan tekanan darah, sampai yang lumayan berat seperti menurunkan kadar gula, menghambat tumbuhnya kanker, atau memulihkan ketergantungan obat.

Sekitar tahun 80-an serat rosella digunakan untuk pembuatan karung dan pakaian. Tapi kemudian nasibnya memburuk digusur pemakaian bahan plastik untuk karung. Tahun 2004, rosella muncul dan terkenal lagi. Pemunculan ini rupanya terkait dengan warna bunganya yang merah. Di kalangan herbalis, warna merah bukan cuma berarti berani tapi sering dikaitkan dengan khasiat untuk mengobati penyakit.

Tak salah kalau orang menyebutnya sebagai bunga rosella. Memang yang dijadikan minuman bukan keseluruhan bunga, tapi cuma kelopaknya. Kelopak inilah yang mengandung vitamin $\mathrm{C}$ tinggi. Bahkan kandungannya sembilan kali lebih banyak dibandingkan dengan vitamin $\mathrm{C}$ di dalam jeruk sitrus dan sepuluh kali lipat dibandingkan dengan belimbing. Setiap $100 \mathrm{~g}$ kelopak rosella segar mengandung $260-280 \mathrm{mg}$ vitamin C. Jumlah itu tiga kali lipat kadar vitamin pada anggur hitam. Seperti kita tahu, di dalam tubuh, vitamin $\mathrm{C}$ alami ini berfungsi membantu memperbaiki metabolisme dan meningkatkan daya tahan tubuh.

Kelopak bunga rosella juga kaya vitamin A, kalsium, kalium, zat besi, natrium, karbohidrat, serat, dan zat-zat gizi lain. Kombinasi dari beberapa jenis nutrisi ini digunakan oleh para herbalis untuk membuat resep menurunkan lemak badan. Juga program diet buat penderita kencing manis dan mencegah osteoporosis.

Di sejumlah negara di Afrika, India, dan Meksiko, rosella dikategorikan sebagai obat tradisional. Kira-kira seperti jamu di Indonesia. Ekstrak kelopak bunga rosella berkhasiat antikejang, anticacing, antibakteri, bahkan bisa mematikan mycobacterium tuberculosis, kuman penyebab tuberkulosis. Khasiat lain adalah sebagai penetral alkohol. Uji praklinik pada unggas menunjukkan bahwa ekstrak rosella menurunkan tingkat penyerapan alkohol sehingga menurunkan efek alkohol di dalam tubuh. Di Guatemala malah jadi salah satu obat terapi pecandu narkoba.

Sumber: Intisari, Agustus 2009, hlm. 104-110

Pilihlah satu jawaban berikut yang menurut Anda benar dengan menyilang huruf $A, B, C$, atau D.

Mengapa nama rosella menarik perhatian? Karena...

(A) khasiatnya mengusir berbagai keluhan tubuh.

(B) warna bunganya merah cabai.

(C) dapat digunakan untuk pembuatan karung dan pakaian.

(D) rasanya yang asem-asem segar.

Pada contoh di atas empat opsi jawaban yang tercantum dalam bacaan adalah opsi (A) khasiatnya mengusir berbagai keluhan tubuh. Hal tersebut dapat dilihat dari bentuk pertanyaannya yang menggunakan kata tanya "mengapa" dan jawaban yang tercantum dalam bacaan adalah khasiatnya mengusir berbagai keluhan tubuh, yaitu pada kutipan bacaan berikut.

Nama rosella tiba-tiba menarik perhatian, tentu karena khasiatnya mengusir berbagai keluhan tubuh. Mulai dari yang ringan seperti menjaga stamina, menurunkan panas, menurunkan tekanan darah, sampai yang lumayan berat seperti menurunkan kadar gula, menghambat tumbuhnya kanker, atau memulihkan ketergantungan obat.

\section{How}

Kata tanya how 'bagaimana'berisi pertanyaan-pertanyaan yang mengandung cara atau proses berlangsungnya suatu peristiwa. Kata tanya ini sama dengan kata 
tanya why 'mengapa', yaitu tidak selamanya penggunaan kata tanya ini menghasilkan soal yang bersifat faktual. Soal dikatakan bersifat faktual jika opsi jawaban tertera atau eksplisit di dalam bacaan. Contoh pertanyaan yang menggunakan kata tanya how 'bagaimana'. Bagaimana peristiwa itu bisa terjadi? Bagaimana dia melakukan perbuatan itu? Bagaimana dia bertemu dengannya pertama kali? Bagaimana cara memecahkan masalah ini? Bagaimana dia menyelesaikan semua pekerjaannya?

\section{Bacalah bacaan berikut! "RACUNKELUAR SAAT BERPUASA"}

Proses detoksifikasi tidak sederhana. Ada lima tahapan yang berlangsung dalam 40 hari. Tahap pertama berlangsung dua hari. Pada tahap ini kadar gula darah turun sampai di bawah 70 $\mathrm{mg} / \mathrm{dl}$. Untuk menutup kekurangan, glikogen dari lever diubah menjadi glukosa. Glikogen juga diambil dari otot sehingga tubuh menjadi lemas. Untuk menghemat enegi, basal metabolic rate (BMR) diturunkan sehingga denyut jantung melambat dan tekanan darah turun. Healing crisis terjadi pada tahap ini: sakit kepala, pusing, mual, napas bau, mata berkabut, dan lidah yang terasa tebal. Tahap ini mungkin ditandai dengan rasa lapar yang kuat.

Tahap kedua berlangsung mulai hari ke-3 sampai ke-7. Tubuh mulai menyesuaikan diri. Sistem pencernaan istirahat. Energi dipusatkan untuk pembersihan dan pemulihan. Lemak diurai untuk melepas gliserol yang diubah menjadi glukosa. Oksidasi lemak menghasilkan keton-keton yang menekan selera makan. Mungkin muncul jerawat atau bisul karena lemak-lemak rusak mulai dikeluarkan dari tubuh. Organ-organ pembersih mulai diperbaiki, termasuk paru-paru. Jadi, kalau paru-paru terasa nyeri, tidak perlu merasa takut. Perbaikan juga menyentuh usus besar. Plak pada dindingnya mulai melunak dan lepas. Napas masih bau dan lidah terasa tebal.

Seminggu kemudian merupakan tahap ketiga. Tahap ini ditandai dengan peningkatan energi, pikiran yang lebih jernih, dan tubuh yang terasa lebih fit. Luka lama mungkin terasa nyeri kembali karena daya sembuh dari tubuh yang meningkat. Sel-sel darah putih mengeluarkan zat yang dapat melarutkan sel-sel mati. Zat inilah yang menimbulkan rasa nyeri pada syaraf di sekitar bekas luka. Nyeri ini menjadi penanda bahwa proses penyembuhan hampir berakhir. Nyeri (dan tegang) juga terasa pada otot karena iritasi toksin, terutama di kaki tempat toksin terkumpul. Persoalan lain ialah munculnya sariawan karena bakteri yang berlebihan di mulut. Atasilah dengan berkumur air garam.

Sisa hari sampai tahap detoksifikasi selesai merupakan tahap keempat. Tubuh sudah beradaptasi sehingga energi meningkat. Pikiran yang lebih jernih terasa setelah hari ke-20. Emosi menjadi stabil; daya ingat dan konsentrasi meningkat. Kerja tubuh dalam mengganti sel-sel yang rusak maksimum. Keseimbangan homeostatik mencapai tingkat optimal. Sistem getah bening sudah bersih, tapi lendir mungkin masih keluar melalui hidung dan tenggorokan. Napas sudah normal. Jadi, rasa percaya diri sudah kembali.

Tahap kelima ialah buka puasa. Saat berbuka, makanan yang masuk akan melepaskan plak pada dinding usus yang sudah melunak. Toksin masuk ke darah dan keluar dari tubuh melalui usus besar. Empedu membuang ampasnya melalui cairan empedu dalam jumlah yang besar. Mungkin dengan diikuti diare. Jika tak nyaman, bisa dibantu dengan colon hydrotherapy.

Sumber: Intisari, No. 543, Oktober 2008, hlm. 52 
Pilihlah satu jawaban berikut yang menurut Anda benar dengan menyilang huruf A, B, C, atau D.

Bagaimana proses detoksifikasi tahap

kelima berlangsung?

(A) Tubuh sudah beradaptasi sehingga energi meningkat. Pikiran yang lebih jernih terasa setelah hari ke20. Emosi menjadi stabil; daya ingat dan konsentrasi meningkat. Kerja tubuh dalam mengganti selsel yang rusak maksimum. Keseimbangan homeostatik mencapai tingkat optimal. Sistem getah bening sudah bersih, tapi lendir mungkin masih keluar melalui hidung dan tenggorokan.

(B) Saat berbuka, makanan yang masuk akan melepaskan plak pada dinding usus yang sudah melunak. Toksin masuk ke darah dan keluar dari tubuh melalui usus besar. Empedu membuang ampasnya melalui cairan empedu dalam jumlah yang besar. Mungkin dengan diikuti diare

(C) Tubuh mulai menyesuaikan diri. Sistem pencernaan istirahat. Energi dipusatkan untuk pembersihan dan pemulihan. Lemak diurai untuk melepas gliserol yang diubah menjadi glukosa. Oksidasi lemak menghasilkan keton-keton yang menekan selera makan. Mungkin muncul jerawat atau bisul karena lemak-lemak rusak mulai dikeluarkan dari tubuh. Organorgan pembersih mulai diperbaiki, termasuk.

(D) paru-paru.

(E) Pada tahap ini kadar gula darah turun sampai di bawah $70 \mathrm{mg} / \mathrm{dl}$. Untuk menutup kekurangan, glikogen dari lever diubah menjadi glukosa. Glikogen juga diambil dari otot sehingga tubuh menjadi lemas. Untuk menghemat enegi, basal metabolic rate (BMR) diturunkan sehingga denyut jantung melambat dan tekanan darah turun.

Pada contoh di atas empat opsi jawaban yang tercantum dalam bacaan adalah opsi (B) Saat berbuka, makanan yang masuk akan melepaskan plak pada dinding usus yang sudah melunak. Toksin masuk ke darah dan keluar dari tubuh melalui usus besar. Empedu membuang ampasnya melalui cairan empedu dalam jumlah yang besar. Mungkin dengan diikuti diare. Hal tersebut dapat dilihat dari bentuk pertanyaannya yang menggunakan kata tanya "bagaimana" dan jawaban yang tercantum pada kutipan bacaan berikut.

Tahap kelima ialah buka puasa. Saat berbuka, makanan yang masuk akan melepaskan plak pada dinding usus yang sudah melunak. Toksin masuk ke darah dan keluar dari tubuh melalui usus besar. Empedu membuang ampasnya melalui cairan empedu dalam jumlah yang besar. Mungkin dengan diikuti diare. Jika tak nyaman, bisa dibantu dengan colon hydrotherapy.

\section{PENUTUP}

Kemampuan jawab guru SLTP dan SLTA di DIY dalam menjawab soal yang bersifat faktual masing-masing adalah $81 \%$. Berdasar sifat soal faktual strategi yang dapat digunakan untuk menjawab bentuk penyoalan ini adalah dengan menggunakan strategi $5 \mathrm{~W} 1 \mathrm{H}$, yaitu who, what, where, when, why, dan how. Strategi ini dapat dijabarkan sebagai berikut. Who ialah tentang siapa? What, apa yang terjadi? Where, di mana peristiwa itu terjadi, when, kapan hal itu terjadi? Why, mengapa hal itu terjadi? How, bagaimana hal itu terjadi?

\section{DAFTAR PUSTAKA}

Maryanto. 2009. "Format Penyusunan Soal UKBI" (hand out). Jakarta: Badan Pengembangan dan Pembinaan 
Totobuang, Vol. 6, No. 1, Juni 2018: 139-154

Bahasa, Kementerian Pendidikan dan Kebudayaan.

Solihah, Atikah. 2014. "Evaluasi Kebijakan Uji Kemahiran Berbahasa Indonesia (UKBI)". Jakarta: Badan Pengembangan dan Pembinaan Bahasa, Kementerian Pendidikan dan Kebudayaan.

-2014. "Penyusunan

Soal UKBI" (hand out, PPT).

Jakarta: Pusat Pengembangan dan PelindunganBadan

Pengembangan dan Pembinaan

Bahasa.
Sudaryanto. 1993. Metode dan Aneka

Teknik Analisis Bahasa:

Pengantar Penelitian Wahana

Kebudayaan Secara Linguistis.

Yogyakarta: Duta Wacana

University Press.

\section{SUMBER DATA}

Intisari, Oktober 2008, hlm. 42

Intisari, Oktober 2008, hlm. 52

Intisari, Agustus 2009, hlm. 104-110 